\title{
Non-Conventional Energy Scenario in India
}

\author{
Ashish Kumar ${ }^{1}$ and Neelam Rawat ${ }^{2}$ \\ THDC Institute of Hydropower Engineering and Technology, Bhagirathipuram, Tehri \\ 249 124, India \\ 1ashish1august@gmail.com, ${ }^{2}$ neelam30october@gmail.com
}

\begin{abstract}
This paper focuses on the review report on the Non-Conventional Energy Scenario in India. Fossil fuels are the main fuel for the energy generation for the worldwide, but it is limited in nature for the next few generations. Therefore, the generation has to change the source of energy from fossil fuels to the current trending energy resources such as non-conventional energy resources. Most of the India Energy Generation is based on conventional energy sources which focus on coal and oil energy and they are limited in nature. Conventional sources are non-bio-degradable and cause more pollution. Whereas non-conventional energy is pollution-free source for energy.
\end{abstract}

Keywords: Non-convention energy, Solar, Wind, Geothermal, Hydropower, Biomass

\section{Introduction}

The high economic growth of India is a well-known fact, which the entire world is aware of but this is an issue of national concern because of the national energy crisis. It is a fact that the other countries are trying to reduce their energy consumption whereas India, on the other hand, is increasing its energy requirement drastically. India is consuming its major energy in the sectors such as Residential, commercial and agricultural purposes when it is compared against Chinese, Japanese and Russian. India as a country began taking concept of energy selfsufficiency very seriously since 1970 due to the oil shocks, which took place in the specified year. The Ministry in India, which is concerned with thi new and renewable energy is MNRE (Ministry of New and Renewable Energy). The specific aim of this organization has been to develop and deploy new renewable energy systems for supplementing the energy requirements of our nation's strength. The Government of India has setup a commission, which has been given charge with the task of formulating all the policies and their implementing programs for developing renewable energy apart with coordinating, intensifying research and development in the concerning sector of the concerned department. The major concerns have been given as their input for solution of the energy scarcity in major sectors of the consumption. The major sources of such energy have been shown as pictorial entity in [Figure 1].

Article history:

Received (February 14, 2019), Review Result (April 28, 2019), Accepted (July 30, 2019) 


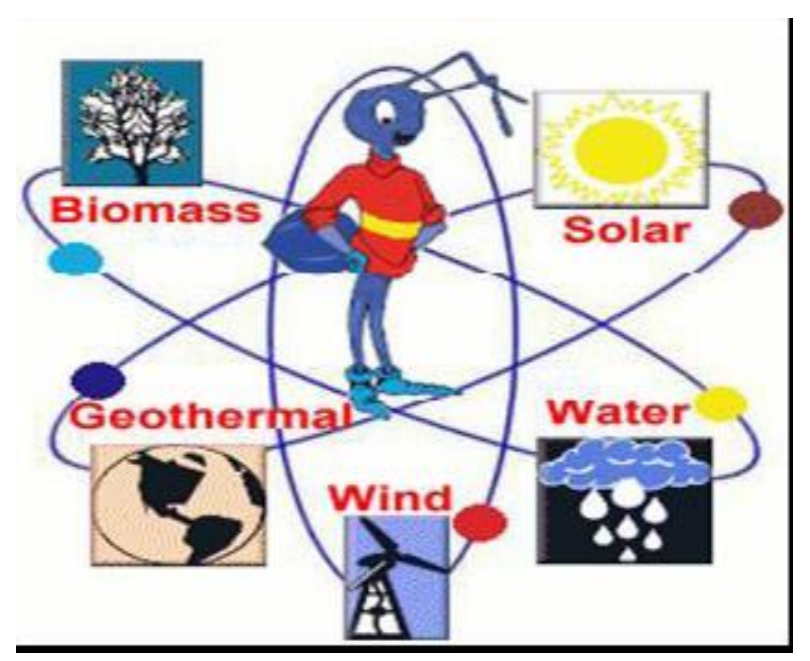

Figure 1. Non-conventional sources of energy

\section{Current scenario of energy generation in India}

The power sector is In India the power sector has been divided in three major sectors they are Central Sector where PSU are main organizations, State Sector, and Private Sector. These sectors have power generation using various source of energy, which include thermal, nuclear, wind, solar, hydro and other such sources. The present capacity of the country has been plotted and shown in Figure 2. There is the following installed capacity as per the Central Electricity Authority (December/21/2017) [1].

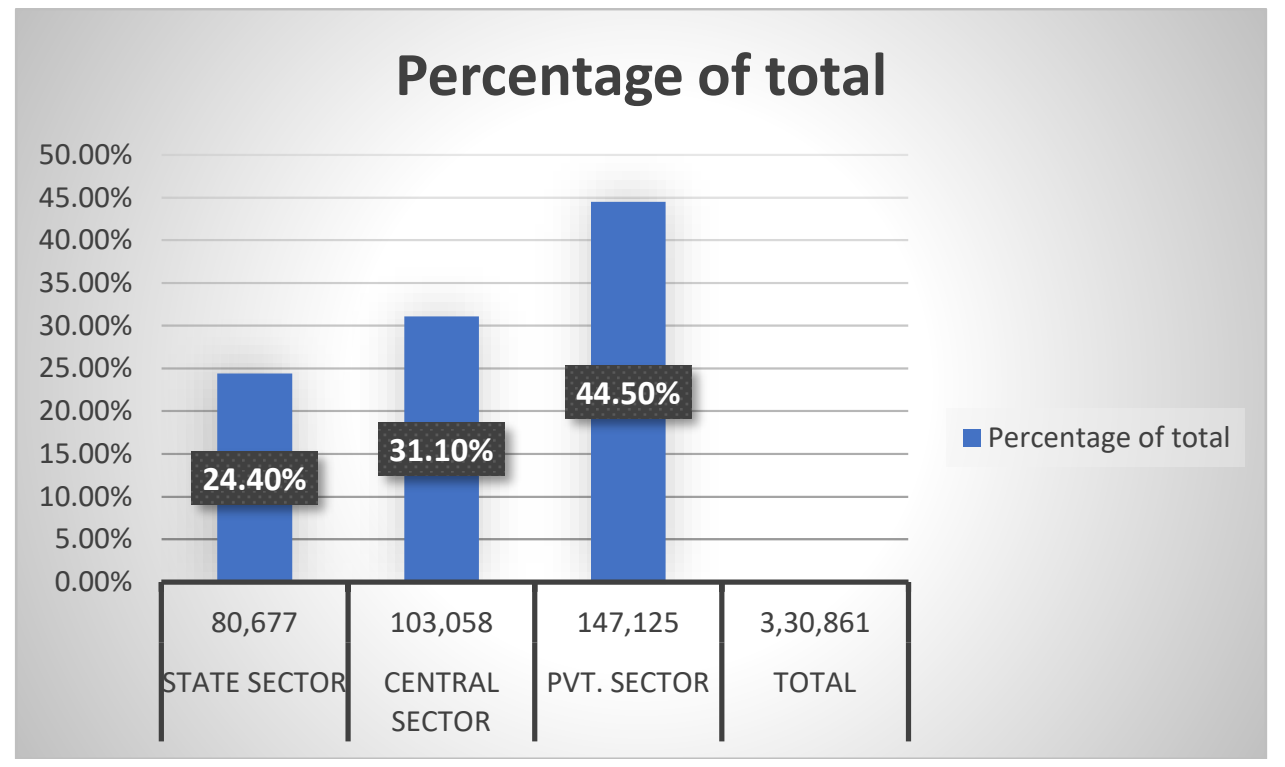

Figure 2. Sector wise power generation 


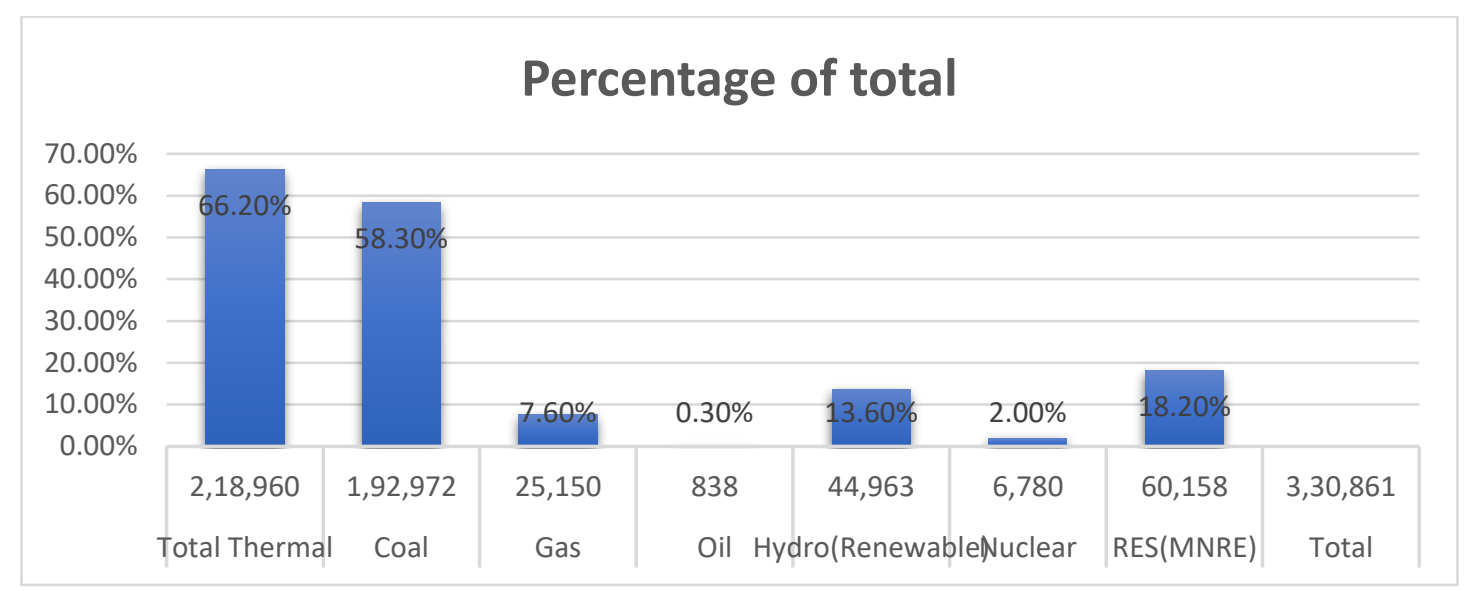

Figure 3. Percentage within section of power

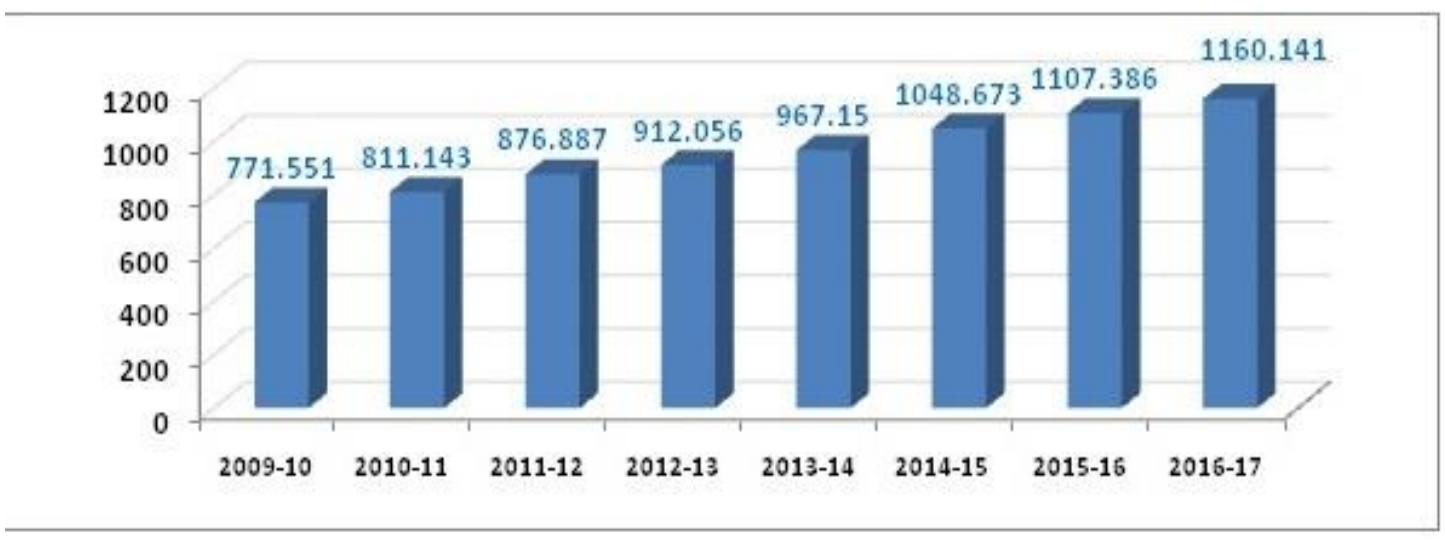

Figure 4. Generation (billion units)

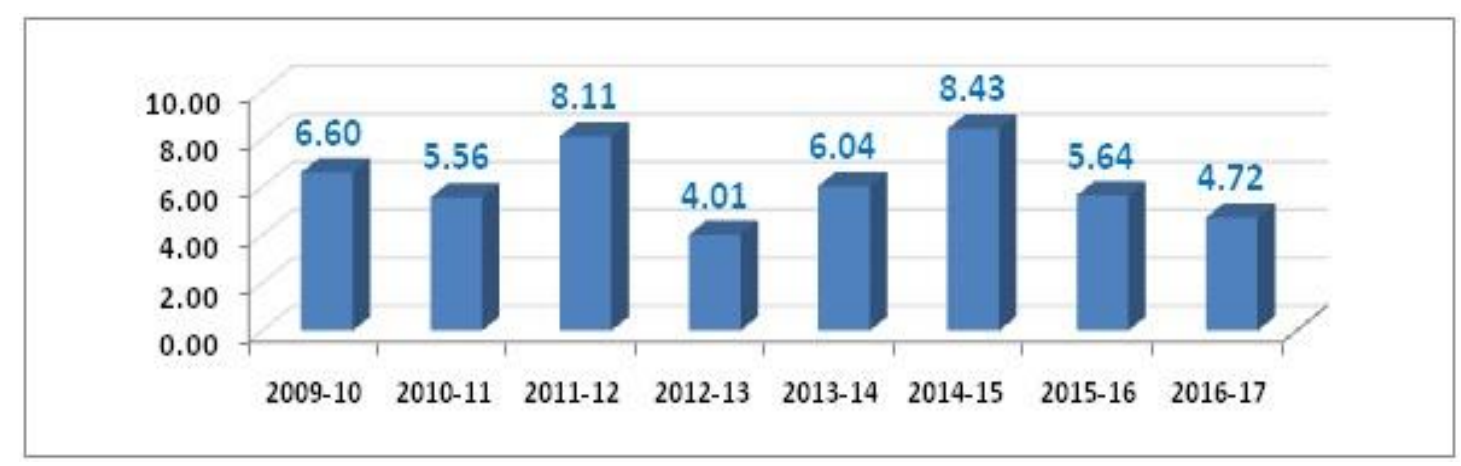

Figure 5. Generation growth (\%)

The total capacity has been shown in various sources and types and yearly growth has been shown in figures from 3 to 5 . The figures are clear indicatives of the total power available in the country and their type has also been shown with approximation. 


\section{Conventional and non-conventional sources of energy}

The word "energy" has been derived from the Greek text "en-ergon" whose meaning is "inwork" or "work content". Therefore, energy may be defined as being the capacity of doing work. The machinery needs the one or another forms of the energy for doing the desired work and for this reason the energy generation is required as per the demand of the work.

The renewable resources taking the examples as wind, water, solar, and geothermal, etc. come from sources that regenerate as fast as they are consumed and are continuously available. The energy sources which are being renewed by nature again and again, and their supply is not at all affected by the rate of their consumption quantity are called renewable energy resources. These are environment-friendly and have potential to replace non-renewable energy resources. These are also known as inexhaustible source of energy. These are available in unlimited amount in nature and can be renewed over relatively shorter period of time. Most of the renewable source of energy are fairly non-polluting and considered as clean [7].

The non-renewable resources, such as fossil fuels and nuclear stuff, are extracted from the earth's crust and can be depleted in near future. These resources have been the most used type of energy in the modern area. In the early part of the twenty-first century, the renewable sources have become more popular as non-renewable sources have begun to deplete.

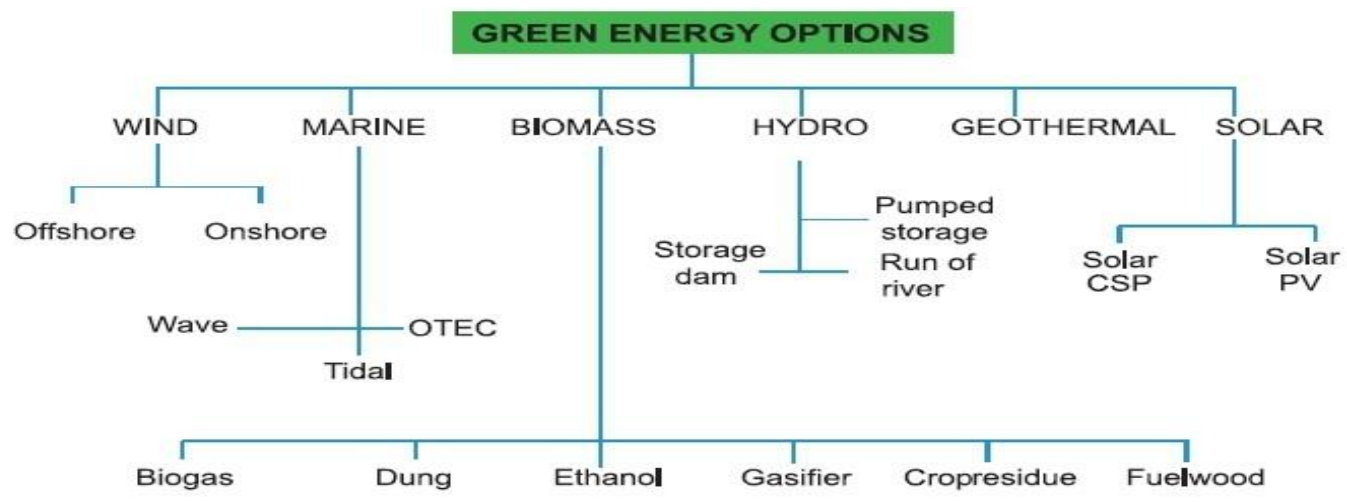

OTEC = Ocean thermal energy conversion

$\mathrm{PV}=$ Photovoltaic

$\mathrm{CSP}=$ Concentrating solar power

Figure 6. Green energy option

\subsection{Solar energy}

The energy radiated by the sun, which reaches the surface of the earth is known as Solar energy. The solar energy can be converted by from one form to another and then it can be utilized in the various forms as per the need of the system. The converted solar energy into other form is then operated upon to produce the useful work it has to supply to humans such as electricity and heat form. Actually, it is the heat of the Sun which gets stored in the fossil fuels and then it is burned in the form of nonrenewable energy which is utilized directly in the raw form of sunlight it can produce a nearly equivalent amount of calorific heat with a negligible amount of carbon content [2]. The solar energy which reaches the earth's atmosphere can be categorized as:

- Beam and diffuse solar radiation

- Attenuation of beam radiation 
The concentrating collector is also known as a focusing lens and it is used to collect the radiation and focus it at the photoelectric cell to convert it into electricity.

\subsection{Wind energy}

Wind energy is actually the kinetic energy possessed by the wind which can be harnessed by the various devices manufactured by man to convert it into electricity. When the solar radiations from the Sun enter the earth's atmosphere the unequal surface of the earth causes the differential heating of the surface of the earth due to this differential heating of the earth's surface some regions receive higher energy whereas certain regions which remai8n in shade are comparatively cooler causing the air over the warmer regions to rise as the warmer air is lighter than the cold as the warm air has less density when taken in ratio with the cold air due to this comparative difference of densities the warmer air is cooler than the cold air hence the warm air rises and the cold air rushes to take its place due to this movement of air the molecules of air which moves with higher kinetic energy cause the movement of air with high velocity known as wind. The wind in the Northern region blows from north to south and vice versa in the Southern region. Then this wind's kinetic energy can be utilized to turn the turbines of the windmill and this mechanical energy can not only be utilized to create electricity but also can be used to grind corn, pump water and even to sail ships. Nowadays this wind energy is used upon good technology to produce electricity [2].

\subsection{Bioenergy}

Bioenergy is mainly manufactured from the biomass the biomass mainly comprises of cattle dung which is then treated in a manufacturing process to act it upon by the bacteria and other components of nature to convert it into usable fuel which can be used to convert its energy into heat energy due to its calorific value is equivalent to that of coal and can even be converted into electricity which is the current oxygen of our generation. The burning of biomass does not produce any extra carbon as the carbon it produces while burning is equal to the carbon it absorbs while it is in the manufacturing process hence no net pollution is caused to the environment by the burning of this fuel [2].

\subsection{Hydro energy}

Water flows from a region of higher potential to a region of lower potential due to the concept of water seeks its own level due to this criterion the water falls from the height to a region of lower potential. This potential energy can be converted to useful energy as the turbine can be installed in such a way that it causes the water to rotate it and then produce energy in the form of electricity.

\subsection{Geothermal energy}

Geothermal energy can be broken as Geo and Thermal Geo means earth and thermal means heat hence geothermal completely means the heat energy stored in the earth. The heat comes out of earth in the form of steam at hot springs then this steam of the spring can be used to turn the turbine and generate electricity hence generate work causing power from a source whose energy otherwise would have been lost but this energy cannot be full fill the rising requirement of humans as the steam of the springs causes the erosion of blades of the turbines [3].

\subsection{Ocean energy}


The ocean also has the energy in the form of a temperature difference as the upper layers of the water get heated up causing the temperature to rise whereas the temperature in the lower region remains cold. This temperature difference can be used to generate electrical energy in addition to this there is even mechanical energy in the form of tides and waves which also produces energy in the form of electricity when converted properly causing great use of this untapped energy [4]. The ocean energy has not been very in use but still it can play a role in energy gap maintenance.

\subsection{Hydrogen energy and fuel cells}

In Hydrogen and Cells known as Fuel Cells, electricity is being produced through an electrochemical reaction taking place between the gases namely hydrogen a gas having no neutrons and oxygen a gas having an atomic number as in [7]. The fuel cells are efficient than other cells, compact when compared with the rest of the cells and reliable than the available cells for various applications [5]. Hydrogen gas having no neutron is the primary fuel for fuel cells can be widely used once they become commercially available in this world. This might take a lot of time to design a system as such. Hydrogen has high-energy content when burnt in the presence of air, it produces only water as a by-product which is a plus point and is easy to use, therefore, environmentally sound which means that it causes no pollution and even has ' 0 ' hazardous effects. At present hydrogen is available as a by-product from industries working in this field [3].

\section{Present status of non-conventional energy source/renewal energy sources in India}

In India, the Department of Non-Conventional Energy Sources has been created in Ministry of Energy in the year 1982 i.e. in the $19^{\text {th }}$ century to look after the aspects relating to renewable energy available in this world. The Department was upgraded into a separate Ministry of NonConventional Energy Sources in 1992 and was renamed as Ministry of New and Renewable Energy in 2006. According to the information furnished by MNRE, there has been consistently increasing in the pace of renewable energy development. Reportedly, India's renewable energy installed capacity has shortly and effectively grown at an annual rate of $23 \%$, rising from about $3900 \mathrm{MW}$ in 2002-03 to about $24000 \mathrm{MW}$ in 2011-12. Energy generated by using wind, solar, small hydro, tides, geothermal heat and biomass is known non-conventional energy as this is not used in the conventional role and is emerging newly. All these sources are a renewable process of energy generation and do not cause environmental pollution which is a major plus point hence these can be easily used and do not cause any harm.

Table 1. Plan - wise renewable power growth in India

\begin{tabular}{|c|c|c|c|c|c|}
\hline Type of Energy & $\begin{array}{c}\text { Starting of } 10^{\text {th }} \\
\text { Plan (MW) } \\
1.4 .02\end{array}$ & $\begin{array}{c}\text { Starting of } 11^{\text {th }} \\
\text { Plan(MW) } \\
1.4 .07\end{array}$ & $\begin{array}{l}\text { Target } 11^{\text {th }} \\
\text { Plan (MW) }\end{array}$ & $\begin{array}{c}11^{\text {th }} \text { Plan } \\
\text { Achievement } \\
\text { as on } \\
\text { 31.3.12 (MW) }\end{array}$ & $\begin{array}{c}\text { Cumulative } \\
\text { Achievement } \\
\text { up to } 31.3 .12 \\
\text { (MW) }\end{array}$ \\
\hline Wind & 1,628 & 7,092 & 9,000 & 10,260 & 17,353 \\
\hline Small Hydro & 1,434 & 1,976 & 1,400 & 1,419 & 3,395 \\
\hline Bio power & 389 & 1,184 & 1,780 & 2,042 & 3,225 \\
\hline Solar & 2 & 3 & 200 & 938 & 941 \\
\hline Total & 3,453 & 10,255 & 12,380 & 14,659 & 24,914 \\
\hline
\end{tabular}


Our country has been endowed with enough natural resources that it does not need any form of unconventional resource [6][7][8][9][10]. The state of energy in the country need to be calculated in real terms, which has not been done perfectly in any country. This needs to be taken into consideration before planning of any source of energy.

[Table 1] shows the Plan wise renewable power growth, as presented by the Ministry of New and Renewable Energy [6].

[Table 2] shows the estimated protentional and installed capacity of various renewable energy sources in India (as per MNRE).

Table 2. Estimated potential and installed capacity of different renewable energy source in India

\begin{tabular}{|c|c|c|c|c|}
\hline Source & $\begin{array}{c}\text { Estimated Potential } \\
(\mathrm{MW})\end{array}$ & $\begin{array}{c}\text { Installed capacity } \\
\text { by end of 11 } \\
31.3 .2012\end{array}$ & $\begin{array}{c}\text { Capacity addition } \\
\text { target for 12 } \\
(2012-17)\end{array}$ & $\begin{array}{c}\text { Target installed } \\
\text { capacity at the end } \\
\text { of the } 12^{\text {th }} \text { Plan }\end{array}$ \\
\hline Wind & 49,000 & 17,353 & 15,000 & 32,553 \\
\hline Small Hydro & 15,000 & 3,395 & 2,100 & 5,495 \\
\hline Biomass power & 17,000 & 1,150 & 500 & 1,650 \\
\hline $\begin{array}{c}\text { Bagasse } \\
\text { Cogeneration }\end{array}$ & 5,000 & 1,985 & 1,400 & 3,385 \\
\hline Waste to power & $2,600-1,300$ & 90 & 500 & 590 \\
\hline Solar Power & $>100,000$ & 941 & 10,000 & 10,941 \\
\hline Total & $>1,89,900$ & 24,914 & 29,500 & 54,414 \\
\hline
\end{tabular}

\section{Advantages of non-conventional energy technologies/renewable energy technologies}

The various advantages of renewable energy technologies are as the following list shows:

a) It is known as an indispensable source of energy which is available in considerable quantity to all the developing nations of the world. This is that source of energy which is having a very significantly impacting trend on the economy of a country.

b) Several renewable options of energy are economical and financial which can be known as to be competitive for some applications of the energy in this world.

c). Renewable energy sources are known to have low energy density when compared and cause very less pollution in scope of energy or ecological balance problem is completely nullified

d) The working power plants based on renewable energy given by the world do not have any working fuel cost or price and hence operate solely on negligible running cost which means no input is given.

e) There is going to be huge scope for research and development in the field of renewable energy sectors which in some scope are regarding its future development and scientific utilization purposes.

f) The use of renewable energy is helping generate local employment if conservation technologies are going to be designed, manufactured, assembled and installed locally in a nation as a whole then it can cause its development.

\section{Bottlenecks and constraints}

There are several hurdles or obstacles which can be better known as hiccups concerned with the development of renewable energy sectors in developing nations this term should be focused upon as these difficulties only arise in the developing nations. These are: 
A. Non-conventional energy Technologies are capital intensive which means that they require high initial investment due to the reason that they have to begin their working from scratch.

B. The power purchase policy has not been encouraging for private entrepreneurs or any other initiators that means they would not be able to generate enough revenue to support themselves.

C. Adequate number of professionally skilled manpower i.e. the workers working efficiently in any industry has not been developed in the non-conventional energy sector for solving the purpose

D. The cost of non-conventional better known as renewable energy gadgets or devices which are being efficiently used such as solar cooker, biogas, solar geysers, solar lanterns etc., is very high

E. Technologies for several non-conventional energy sources are not fully stabilized to work efficiently.

\section{Process for good and efficient used in renewable energy technology}

For development, dissemination and efficient use of renewable energy technologies in the country, some of the steps have already been taken at the level of Government and at other higher committees in different organizations. the following steps may be suggested:

To set up wind, biomass or solar power generation systems and energy saving in every government office to encourage people. It even includes laying the foundation of the national level body to increase awareness of renewable energy at a comprehensive level. It even aims to train technical manpower for non-conventional or the better-suited name the renewable energy sectors. The steps even consider making it compulsory to install solar power plants. The major step is to restrict the use of large battery energy storage systems and promoting the use of biofuels in vehicles. The major step is to provide Handsome incentives and subsidies for installation and successful operation of non-conventional/renewable energy equipment and additional incentives for buyers and manufacturers of renewable energy equipment in rural areas. The most important step taken to now is the Cultivation of energy crops on marginal and degraded land. The most widely accepted step is that of Abrogating duties/taxes on import of small-scale non-conventional/renewable energy generating equipment and providing manageable loans for setting up non-conventional/renewable energy enterprises. The most widely circulated step has been Imperative non-conventional/renewable energy systems provision for new residential, commercial and industrial buildings. It even includes Establishing aspiring goals and targets for power generation non-conventional/renewable sources. The main aim is to Research and development of renewable energy technologies get provided the financial support and sponsorship with the major step can be too Strenuous exaltation of renewable energy by government agencies, public sector, corporate, academic institutions. For example: "Figure 1. Database contexts", "Table 1. Input data". Figure captions are to be below the figures. Table titles are to be centered above the tables.

\section{Conclusion}

The sustainable development and growth of any country is somewhat dependent on the development and security of its energy sectors, which are directly responsible for and related to the economy's growth. It is well-known fact that there are finite and limited reserves of most of the conventional energy sources. Apart from this their impact on the environment has major effect, which is negative in terms of health of environment. These are the reasons for having 
great emphasis on the development of non-conventional energy sectors and their proper utilization for the benefit and betterment of humans living on earth. There should be initiatives and efforts to get benefit of the technology available and to develop new technology and use the renewal resources of energy and keep track of the effect on the environment during extraction of such energy. This will certainly help in creation of employment opportunities at all levels of life, especially in rural areas rather than urban areas or suburban areas. In India, the Department of Non-Conventional Energy Sources has been created in Ministry of Energy in the year 1982 to look after the aspects relating to renewable energy available in this world and make use of the sources without affecting the environment and the ecosystem.

\section{References}

[1] Government of India ministry of power, "Power sector at a glance all India", https://powermin.nic.in/en/content/power-sector-glance-all-india, (2019)

[2] "Application of non-conventional \& renewable energy sources," Link: https://beeindia.gov.in/sites/default/files/4Ch12.pdf

[3] Singal, S. K. and Varun, "Development of non-conventional energy sources," 9th NCB International Seminar on Cement and Building Materials, New Delhi, Nov, pp.8-11, (2005)

[4] G.D. Rai, "Non-conventional energy sources," KHANNA Publishers, fifth Edition: April, pp.495, (2011)

[5] Y. A. Sadawarte, R. T. Hiware, P. Pathak, and S. Tripathi, "Non-conventional sources of energy," IJCA Proceedings, International Conference, Emerging Frontiers in Technology for Rural Area (EFITRA-2012), (2012)

[6] "Availability of identified non-conventional resources of energy - their potential vis-à-vis utilization," 29th Report, Standing Committee on Energy (2011-12), MNRE, India, (2012)

[7] Jitender Saroha, "Nonconventional energy resources in India," Spatial Diversity and Dynamics in Resources and Urban Development, pp.431-447, (2015)

[8] Gautam Khurana, "Renewable energy in India: Current status and future potential," Indiary Foundation, (2018)

[9] Praveer Sinha and Tata Power, "The future of renewable energy in India," Energy World, (2018)

[10] "Central statistics office ministry of statistics and programme implementation government of India," Energy Statistics, vol.25, (2018) 
Non-Conventional Energy Scenario in India

This page is empty by intention. 